\title{
Effects of increased soil water availability on grassland ecosystem carbon dioxide fluxes
}

\author{
Anita C. Risch · Douglas A. Frank
}

Received: 25 January 2007 / Accepted: 2 July 2007 / Published online: 3 August 2007

(C) Springer Science+Business Media B.V. 2007

\begin{abstract}
There is considerable interest in how ecosystems will respond to changes in precipitation. Alterations in rain and snowfall are expected to influence the spatio-temporal patterns of plant and soil processes that are controlled by soil moisture, and potentially, the amount of carbon (C) exchanged between the atmosphere and ecosystems. Because grasslands cover over one third of the terrestrial landscape, understanding controls on grassland $\mathrm{C}$ processes will be important to forecast how changes in precipitation regimes will influence the global $\mathrm{C}$ cycle. In this study we examined how irrigation affects carbon dioxide $\left(\mathrm{CO}_{2}\right)$ fluxes in five widely variable grasslands of Yellowstone National Park during a year of approximately average growing season precipitation. We irrigated plots every 2 weeks with $25 \%$ of the monthly 30 -year average of precipitation resulting in plots receiving approximately $150 \%$ of the usual growing season water in the form of rain and supplemented irrigation. Ecosystem $\mathrm{CO}_{2}$
\end{abstract}

\section{A. C. Risch · D. A. Frank}

Department of Biology, Biological Research Laboratory, Syracuse University, 130 College Place, Syracuse, NY, 13244, USA

\section{A. C. Risch $(\square)$}

Swiss Federal Institute for Forest, Snow and Landscape Research, Research Unit Community Ecology, Research Group Animal Ecology, Zuercherstrasse 111, 8903, Birmensdorf, Switzerland

e-mail: anita.risch@wsl.ch fluxes were measured with a closed chamber-system once a month from May-September on irrigated and unirrigated plots in each grassland. Soil moisture was closely associated with $\mathrm{CO}_{2}$ fluxes and shoot biomass, and was between $1.6 \%$ and $11.5 \%$ higher at the irrigated plots (values from wettest to driest grassland) during times of measurements. When examining the effect of irrigation throughout the growing season (May-September) across sites, we found that water additions increased ecosystem $\mathrm{CO}_{2}$ fluxes at the two driest and the wettest sites, suggesting that these sites were water-limited during the climatically average precipitation conditions of the 2005 growing season. In contrast, no consistent responses to irrigation were detected at the two sites with intermediate soil moisture. Thus, the ecosystem $\mathrm{CO}_{2}$ fluxes at those sites were not water-limited, when considering their responses to supplemental water throughout the whole season. In contrast, when we explored how the effect of irrigation varied temporally, we found that irrigation increased ecosystem $\mathrm{CO}_{2}$ fluxes at all the sites late in the growing season (September). The spatial differences in the response of ecosystem $\mathrm{CO}_{2}$ fluxes to irrigation likely can be explained by site specific differences in soil and vegetation properties. The temporal effects likely were due to delayed plant senescence that promoted plant and soil activity later into the year. Our results suggest that in Yellowstone National Park, above-normal amounts of soil moisture will only stimulate $\mathrm{CO}_{2}$ fluxes across a portion of the ecosystem. Thus, depending on the topographic 
location, grassland $\mathrm{CO}_{2}$ fluxes can be water-limited or not. Such information is important to accurately predict how changes in precipitation/soil moisture will affect $\mathrm{CO}_{2}$ dynamics and how they may feed back to the global $\mathrm{C}$ cycle.

Keywords Net ecosystem $\mathrm{CO}_{2}$ exchange . Plant assimilation - Ecosystem respiration .

Soil respiration - Plant respiration .

Closed chamber - Irrigation - Soil moisture .

Climate change $\cdot$ Altered precipitation regime

\section{Introduction}

Global temperature and precipitation regimes are expected to change as a consequence of increasing levels of atmospheric carbon dioxide $\left(\mathrm{CO}_{2}\right)$ and other greenhouse gases (Oreskes 2004). Predicted changes in the amount and frequency of precipitation at both seasonal and annual scales will affect the variation in soil moisture and the plant and soil processes influenced by soil moisture (Lauenroth and Sala 1992; Knapp et al. 2002). Generally, under non-saturated soil conditions, water additions trigger short-term increases in microbial activity and plant assimilation/ respiration, with plants reacting somewhat slower (hours to days) compared to microbes (hours; e.g., Sala and Laurenroth 1982; Huxman et al. 2004a, b). Longer-term (annual-decadal) responses of nonsaturated systems to water additions are, in contrast, related to increases in soil and plant $\mathrm{CO}_{2}$ fluxes associated with changes in plant community composition and/or structure and associated changes in the composition of the decomposer community (e.g., Brown et al. 1997; Knapp et al. 2002; Tylor et al. 2004). Once a system becomes saturated, non-water limited or even anoxic soil conditions may predominate and both soil and plant $\mathrm{CO}_{2}$ fluxes decrease (e.g., Kozlowski 1984; Bouma and Bryla 2000). Thus, changes in precipitation regimes will affect the assimilation and loss of carbon (C) depending on how water-limited photosynthetic and metabolic processes are among members of the ecosystem.

Grasslands cover approximately one-third of the earth's terrestrial surface area (Lieth 1978), and store between $10 \%$ and $30 \%$ of the world's soil C (Anderson 1991; Eswaran et al. 1993). Consequently, small precipitation-associated changes in $\mathrm{C}$ pools and fluxes within these systems could have a considerable impact on the global $\mathrm{C}$ cycle. Most studies that investigated the effect of variable precipitation on ecosystem $\mathrm{CO}_{2}$ fluxes in grasslands limited their investigation to (i) differences found across large scales (regional, continental; e.g., see articles in Soussana et al. 2007), or (ii) to the variability at a single location only (e.g., Fay et al. 2000, 2003; Meyers 2001; Liu et al. 2002; Suyker et al. 2003; Hunt et al. 2002, 2004; Huxman et al. 2004a; Chimner and Welker 2005; Flanagan and Johnson 2005; Harper et al. 2005; Jaksic et al. 2006).

Yet, grasslands are spatio-temporally heterogeneous landscapes, where topography creates smallscale spatial differences in soil texture and moisture (e.g., Schimel et al. 1985; Frank et al. 1994), C and nitrogen content (e.g., Frank et al. 1994; Turner et al. 1997), and plant composition and production (e.g., Abrams et al. 1986; Frank and McNaughton 1992; Lauenroth and Sala 1992; Knapp et al. 1993; Briggs and Knapp 1995). Additionally, temporal (i.e., monthly and annual) changes in air temperature and precipitation alter plant and soil processes (Lauenroth and Sala 1992; Briggs and Knapp 1995; Epstein et al. 2002; Knapp et al. 2002). Consequently, the responses of grassland ecosystem $\mathrm{CO}_{2}$ fluxes to changes in precipitation are likely to be spatiotemporally heterogeneous. To our knowledge, there is no information available on how the spatio-temporal variation that is characteristic of most grassland ecosystems may interact with changes in precipitation to control grassland $\mathrm{CO}_{2}$ fluxes.

The objective of this study was to measure the effect of irrigation on ecosystem $\mathrm{CO}_{2}$ fluxes among five widely variable grasslands in Yellowstone National Park during a year of approximately average growing season precipitation. Therefore we assessed whether grassland $\mathrm{CO}_{2}$ fluxes were water-limited during conditions of average soil moisture at different locations within the park, and, if not, where in the landscape ecosystem $\mathrm{CO}_{2}$ fluxes were not water-limited.

\section{Methods}

Study area and sampling design

The study was conducted in the northern part of Yellowstone National Park, located in the 
northwestern corner of Wyoming, USA (44 $55^{\prime} \mathrm{N}$ to $45^{\circ} 10^{\prime} \mathrm{N}$ and $110^{\circ} 10^{\prime} \mathrm{W}$ to $110^{\circ} 50^{\prime} \mathrm{W}$ ). Yellowstone National Park encompasses nearly $9,000 \mathrm{~km}^{2}$ and is home for large migratory herds of elk (Cervus elaphus L.), bison (Bison bison L.), and pronghorn (Antilocarpa americana (Ord.)). Elevations range from roughly $1,500-3,500 \mathrm{~m}$. The climate features long cold winters and short warm summers with an average annual temperature of approximately $1{ }^{\circ} \mathrm{C}$. The average annual precipitation ranges from $260 \mathrm{~mm}$ per year at the north boundary to $2,050 \mathrm{~mm}$ per year in the south west corner of the Park. We selected five sites located on an elevational gradient (Table 1, Fig. 1). They ranged from dry to mesic grassland with different soils and species composition (Table 1).

Within each site, we selected six $2 \times 1 \mathrm{~m}$ plots in homogenous vegetation at the beginning of the 2005 growing season. Three of these plots were randomly chosen for irrigation. The irrigated plots were evenly watered with a watering can every other week from mid-April through late-September 2005 with $25 \%$ of the average monthly 30 -year average of precipitation for a given month (Fig. 2). Consequently, irrigated plots received $50 \%$ of average precipitation as supplemental water. Precipitation data used to calculate the monthly 30-year averages were taken from Mammoth Hot Springs for site 4, Tower Falls for sites 1 and 2, and Lake for sites 3 and 5 (Fig. 1). This assured that differences in mean precipitation among the sites was accounted for in our experiment. Both the control and watered plots were subject to "regular" precipitation events (Fig. 2). Average precipitation totals during the winter preceding the study (November 2004-March 2005) and during the 2005 growing season (AprilOctober) were between $63-89 \%$ and $106-111 \%$ of the 30 -year average, respectively.

\section{Ecosystem $\mathrm{CO}_{2}$ fluxes}

At each irrigated and control plot we measured NEE under different light conditions on a $50 \times 50 \mathrm{~cm}$ area in the center of one half of the $2 \times 1 \mathrm{~m}$ plot. Soil respiration was measured in the center of the other half of the $2 \times 1 \mathrm{~m}$ plot. The measurements were conducted once a month from May to September on clear, sunny days near the solar maximum (between $9.30 \mathrm{~h}$ and $15.30 \mathrm{~h}$ ). $\mathrm{CO}_{2}$ fluxes were measured

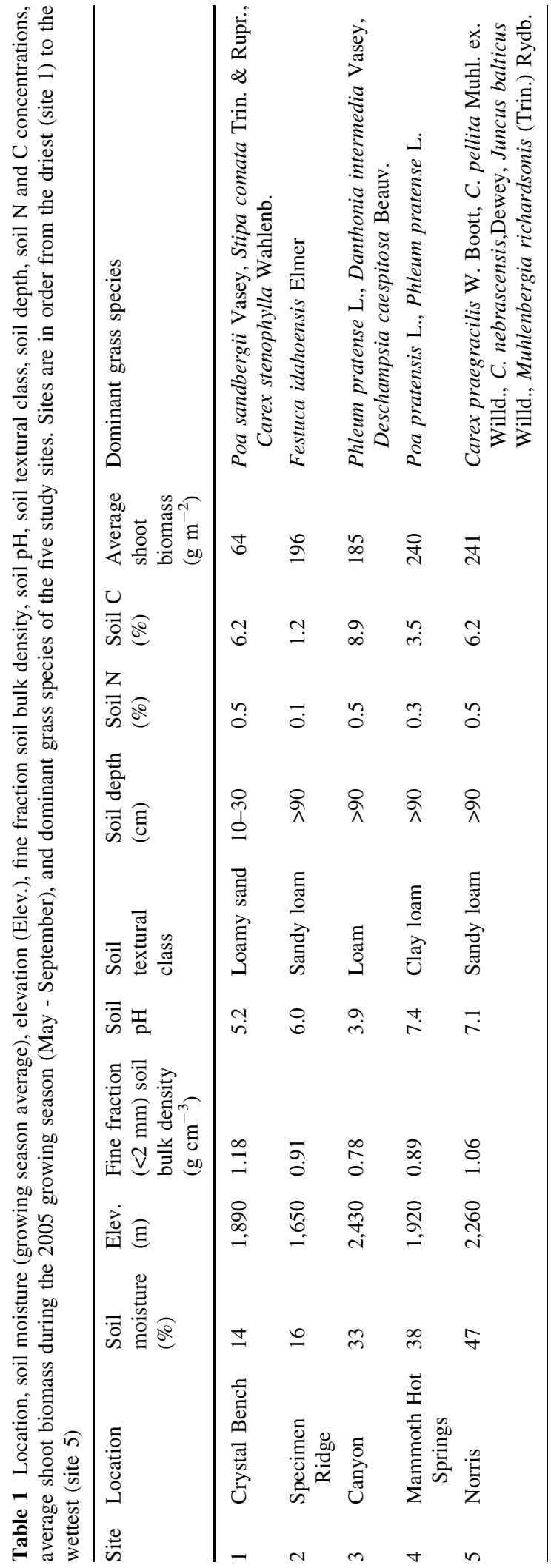




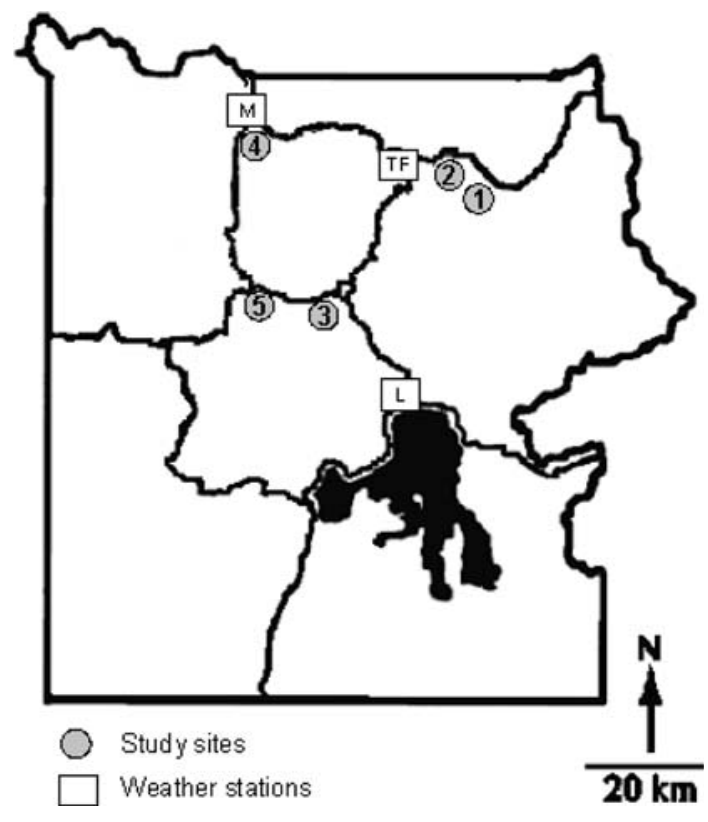

Fig. 1 The locations of the five study sites (grey dots) and three weather stations (white rectangles) in relation to roads in Yellowstone National Park (NOAA daily weather data). 1 = Crystal Bench, $2=$ Specimen Ridge, 3 = Canyon, $4=$ Mammoth Hot Springs, $5=$ Norris; TF $=$ Tower Falls, $\mathrm{M}=$ Mammoth Hot Springs; L = Lake

between 3 and 7 days after an irrigation event (Fig. 2). We are aware that by choosing such a measuring design we did not include short-term responses (1-2 days) of the $\mathrm{CO}_{2}$ fluxes to irrigation, which normally includes increased soil respiration as a consequence of water infiltrating soil pores and purging the soil of $\mathrm{CO}_{2}$ (e.g., Huxman and others 2004b). However, our goal was to specifically examine the ecosystem $\mathrm{CO}_{2}$ exchange response to irrigation after the potential $\mathrm{CO}_{2}$ flush from the soil to determine, biological responses of the plant and soil communities to increases in moisture availability. We could not sample $\mathrm{CO}_{2}$ fluxes at site 3 , located at the highest elevation, before July because of snow covering the site till mid June.

We sampled NEE using a temperature controlled $50 \mathrm{~cm} \times 50 \mathrm{~cm} \times 50 \mathrm{~cm}$ closed chamber system (chamber construction followed Wilsey et al. 2002, for specific chamber design used see Risch and Frank 2006). Fluxes were measured for $180 \mathrm{~s}$ after placing the chambers onto foam pads (to seal base) mounted to aluminum frames. Frames were driven three centimeters deep into the soil at least one hour before the first measurement. The chamber was vented for approximately $120 \mathrm{~s}$ after each measurement. NEE (umol $\mathrm{CO}_{2} \mathrm{~m}^{-2} \mathrm{~s}^{-1}$ ) was calculated using

$\mathrm{NEE}=\mathrm{dCO}_{2} / \mathrm{dt}^{*} \mathrm{P} /\left[\mathrm{R}^{*}(273.15+\mathrm{T})\right]^{*} \mathrm{~V} / \mathrm{A}$

where $\mathrm{dCO}_{2} / \mathrm{dt}\left(\mu \mathrm{mol} \mathrm{mol} \mathrm{m}^{-1} \mathrm{~s}^{-1}\right)=\mathrm{CO}_{2}$ accumulation rate inside the chamber during $t$ seconds, based on linear regression, $\mathrm{P}=$ atmospheric pressure $(\mathrm{kPa}), \mathrm{R}=$ gas constant, $8.314\left(\mathrm{kPa} \mathrm{m}^{3} \mathrm{~K}^{-1} \mathrm{~mol}^{-1}\right)$, $\mathrm{T}=$ chamber temperature $\left({ }^{\circ} \mathrm{C}\right), \mathrm{V}=$ chamber volume $\left(\mathrm{m}^{3}\right)$, and $\mathrm{A}=$ chamber bottom area $\left(\mathrm{m}^{2}\right) \cdot \mathrm{CO}_{2}$ accumulation rates were corrected for water vapor (Hooper et al. 2002); air pressure correction was conducted automatically by the LICOR 6262 . Pressure changes within the chamber were assumed to be minimal due to the large volume of the chamber, and the short measurement intervals (Healy et al. 1996).

We determined light-response curves for each grassland plot and sampling date by making two NEE measurements each under full light, 70\% light, 50\% light, 30\% light (measured as photosynthetic photon flux density = PPFD) using different degree shade screens over the chamber, and under $0 \%$ light using a black cloth over the chamber. NEE and PPFD measurements were then used to determine relationships between $\mathrm{CO}_{2}$ flux and light. We fitted linear

$\mathrm{NEE}=\alpha^{*} \mathrm{PPFD}-\mathrm{R}_{\mathrm{eco}}$

and hyperbolic

$$
\begin{aligned}
\mathrm{NEE}= & \left(\alpha * \mathrm{NEE}_{\max } * \mathrm{PPFD} /\right. \\
& \left.\left(\mathrm{NEE}_{\max }+\alpha \mathrm{PPFD}\right)\right)-\mathrm{R}_{\mathrm{eco}}
\end{aligned}
$$

equations following Ruimy et al. (1995), where $\alpha=$ quantum yield (initial slope in the hyperbolic equation), $\mathrm{NEE}_{\max }=\mathrm{NEE}$ maximum (asymptote of the hyperbola), $\mathrm{R}_{\mathrm{eco}}=$ dark respiration (NEE at zero PPFD). Departure from linearity (D) was calculated as $r^{2}$ hyperbolic $-r^{2}$ linear (Ruimy et al. 1995). If $\mathrm{D}$ was $<0.01$, the linear equation was used (Ruimy et al. 1995). We then calculated $\mathrm{NEE}_{1800}$, which was NEE at full light $\left(1,800 \mu \mathrm{mol} \mathrm{s}^{-1}\right.$ PPFD).

Soil respiration was measured with a $20 \mathrm{~cm}$ (high) by $10 \mathrm{~cm}$ (diameter) closed chamber system (for more detail see Risch and Frank 2006). The chamber was slid into PVC collars $(10 \mathrm{~cm}$ diameter) driven five centimeters deep into the mineral soil 
Fig. 2 Daily precipitation and air temperature values between April 1, 2005 and September 30, 2005 recorded at the Park's weather stations in closest proximity to our study sites: (a) Tower Falls, located at 1,910 m (sites 1 and 2), (b) Lake, located at 2,388 m (sites 3 and 5), (c)

Mammoth Hot Springs, located at $1,899 \mathrm{~m}$ (site 4). Vertical arrows indicate time of irrigation events (bi-weekly)
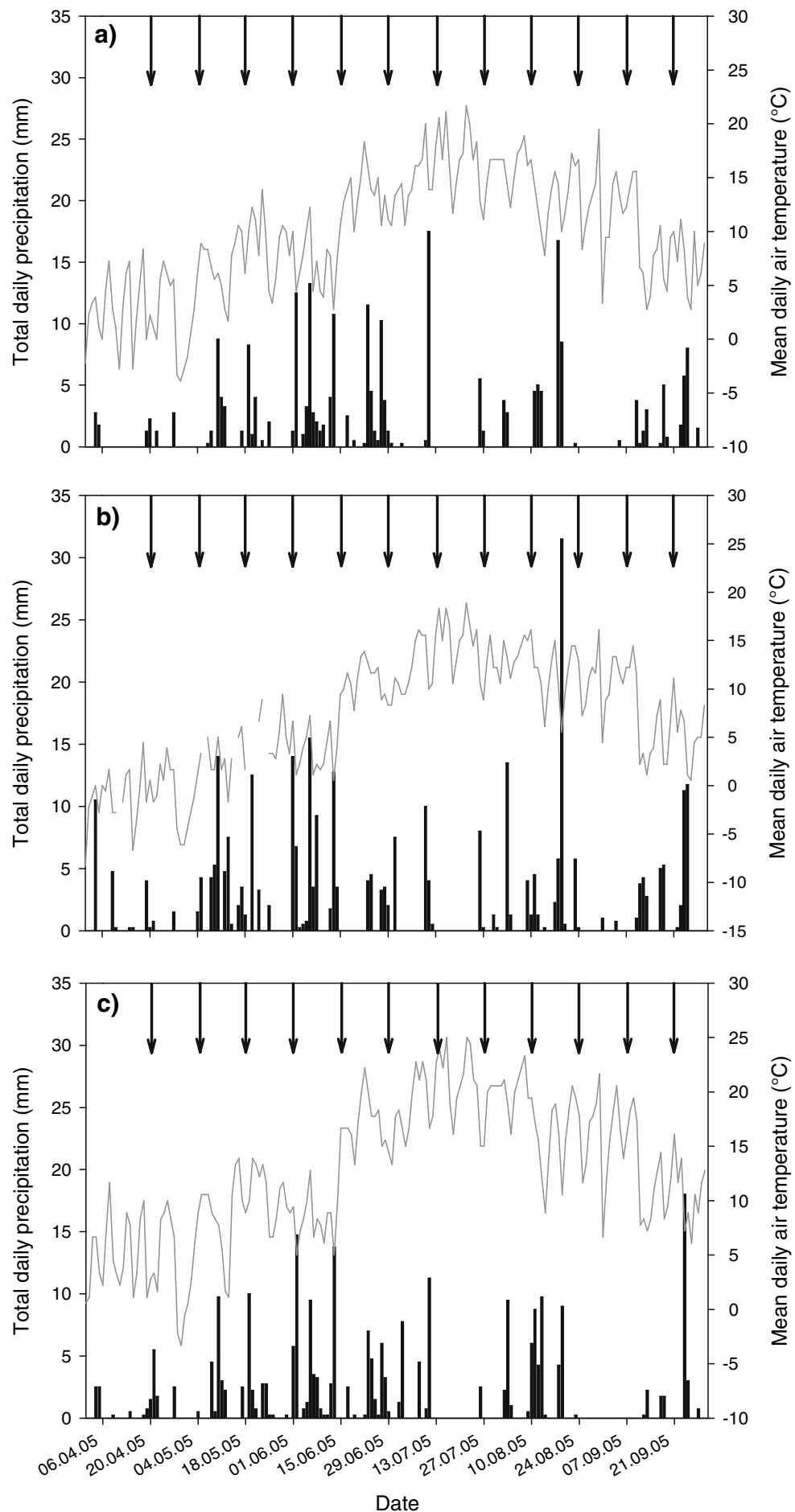

$\downarrow \begin{array}{ll}\text { Irrigation event } \quad \text { Precipitation } \\ & \text { Air temperature }\end{array}$ 
after clipping the vegetation $\geq 40$ min before the first measurement. New locations were randomly assigned for the rings every month. $\mathrm{R}_{\text {soil }}$ was calculated as the mean of two 3 min measurements using Eq. 1. The chamber was calibrated against the LICOR 6400-09 soil respiration system across a wide variety of soils in Yellowstone National Park to explore potential effects of pressure disequilibrium inside the chamber on respiration measurements (e.g., Davidson et al. 2002). We found a significant linear relationship between the two methods (eq. 2: $y=1.061 * x, r^{2}=0.72, P<0.001$, $n=30$, where $y$ is the LICOR 6400-09 soil respiration system and $\mathrm{x}$ our own chamber). More pertinent to the aims of this calibration was that the $\mathrm{X}$ intercept was zero and there was no significant difference between the slope of the regression line and 1.0, indicating that the rates measured with our system were unbiased measures of soil respiration. In order to adjust for potential measurement differences between the different sized soil and NEE chamber, we calibrated these chambers against each other across a wide variety of soils to accurately calculate canopy respiration ( $\mathrm{R}_{\text {canopy }}$ ) by subtracting $\mathrm{R}_{\text {soil }}$ from $\mathrm{R}_{\text {eco }}$ (Eq. 3: $y=0.4833 x+2.5128$, $r^{2}=0.74, P<0.001, n=33$, where $\mathrm{y}$ is the NEE chamber and $x$ our soil chamber). $\mathrm{R}_{\text {soil }}$ measurements were then corrected using Eq. 3. Gross $\mathrm{CO}_{2}$ assimilation (Assimilation) was calculated by summing $\mathrm{NEE}_{1800}$ and total ecosystem respiration $\left(\mathrm{R}_{\text {eco }}\right)$. Negative $\mathrm{CO}_{2}$ flux values were $\mathrm{CO}_{2}$ sources $\left(\mathrm{CO}_{2}\right.$ leaving the ecosystem), positive values were $\mathrm{CO}_{2}$ sinks $\left(\mathrm{CO}_{2}\right.$ absorbed by the vegetation).

\section{Biomass and environmental variables}

We estimated aboveground biomass (biomass) nondestructively on three irrigated and three unirrigated $70 \times 70 \mathrm{~cm}$ plots at each site with a canopy intercept method (Frank and McNaughton 1990). Biomass was estimated within 1 day of the $\mathrm{CO}_{2}$ flux measurements.

Air temperature was recorded every five seconds during the $\mathrm{CO}_{2}$ measurements with an air temperature sensor (HOBO weather station 8-bit temperature/RH smart sensor, Onset Computer, Bourne MA, USA) attached to the top of the NEE chamber and connected to a data logger (Fifteen channel H21
HOBO weather station data logger, Onset Computer, Bourne MA, USA). PPFD also was determined during the $\mathrm{CO}_{2}$ measurements using a photosynthetically active radiation (PAR) sensor (HOBO weather station photosynthetic light (PAR) smart sensor, Onset Computer, Bourne MA, USA) attached to the inside surface of the top of the chamber and was recorded every five seconds on the data logger. Soil temperature (HOBO weather station 8-bit temperature smart sensor, Onset Computer, Bourne MA, USA) also was recorded on the data logger during the $\mathrm{CO}_{2}$ measurements at both plots every five seconds at $20 \mathrm{~cm}$ mineral soil depth, while soil moisture was measured with a time domain reflectometer (TDR 100 soil moisture probe, Spectrum Technologies, Plainfield IL, USA) at six randomly selected locations to a depth of $12 \mathrm{~cm}$ immediately before the $\mathrm{CO}_{2}$ measurements. Average soil moisture for each plot was then derived by averaging the six values. Both soil temperature and moisture were measured within the $2 \times 1 \mathrm{~m}$ plots, $15 \mathrm{~cm}$ from the edge, but outside the area used for $\mathrm{CO}_{2}$ measurements.

\section{Statistical analyses}

We averaged the monthly data for the ecosystem $\mathrm{CO}_{2}$ exchange variables $\left(\mathrm{R}_{\mathrm{eco}}, \mathrm{R}_{\text {soil }}\right.$, Assimilation, $\mathrm{R}_{\text {canopy }}, \mathrm{NEE}_{1800}$ ), aboveground biomass, and soil moisture and used linear regression analyses to evaluate the relationship between the independent variable soil moisture, and the dependent ecosystem $\mathrm{CO}_{2}$ exchange parameters $\left(\mathrm{R}_{\mathrm{eco}}, \mathrm{R}_{\text {soil }}\right.$, Assimilation, $\mathrm{R}_{\text {canopy }}, \mathrm{NEE}_{1800}$ ) for both the treatments separately. Linear regression analysis also was used to explore the relationships between the variables soil moisture and biomass, biomass and ecosystem $\mathrm{CO}_{2}$ fluxes, ecosystem $\mathrm{CO}_{2}$ fluxes and soil $\mathrm{C}$, and between ecosystem $\mathrm{CO}_{2}$ fluxes and air temperature. Irrigation effects on ecosystem $\mathrm{CO}_{2}$ fluxes at each site were determined with two tailed paired $t$-tests ( $\alpha=0.1$ ) using monthly measurements of both irrigated and unirrigated plots at each site. To address the temporal (among months) variation in each of the ecosystem $\mathrm{CO}_{2}$ exchange variables, we used repeated measure ANOVAs. Two tailed paired $t$-tests $(\alpha=0.1)$ were used to assess differences in ecosystem $\mathrm{CO}_{2}$ fluxes between the irrigated and unirrigated plots for each month separately. 


\section{Results}

Ecosystem $\mathrm{CO}_{2}$ fluxes, biomass and soil moisture varied markedly among the five sites. Lowest fluxes generally were found at the driest site (site 1) and highest fluxes occurred at the site where average growing season soil moisture was highest (site 5; Table 1, Fig. 3). Soil moisture was positively and linearly correlated with assimilation, $\mathrm{R}_{\mathrm{eco}}, \mathrm{R}_{\text {soil }}$ and $\mathrm{R}_{\text {canopy }}$ measured in both irrigated and unirrigated grasslands across the Yellowstone landscape (Table 2). No correlation was found between $\mathrm{NEE}_{1800}$ and soil moisture for either of the treatments (Table 2). Soil moisture also was positively related to shoot biomass $\left(r^{2}=0.41, P=0.047\right)$, and shoot biomass was positively related to all the ecosystem $\mathrm{CO}_{2}$ fluxes $(P<0.05$ for all linear regressions). The fluxes were also closely correlated to air temperature (recorded throughout the measurements; $P<0.05$ for all linear regressions). In contrast, none of the flux measurements was correlated to $0-20 \mathrm{~cm}$ mineral soil C concentrations.

Irrigating semi-monthly with a total of $50 \%$ of the 30 -year average precipitation resulted in higher MaySeptember soil moisture by an average of $11.5 \%$ at site $1,5.2 \%$ at site $2,3.2 \%$ at site $3,2.7 \%$ at site 4 and $1.6 \%$ at site 5 , respectively (at times of measurements). Thus, soil moisture content (see Table 1) of unirrigated plots was negatively correlated with increases in soil moisture content due to irrigation. Even though the snow melted much later at site 3 compared to the other sites, average soil moisture during the three months of measurement (July, August, September) was lower than at site 4 and 5 during the same period. At the two driest sites ( $1 \& 2$ ) $\mathrm{R}_{\text {eco }}$ was $7-39 \%$ (site 1) and 1.5$29 \%$ (site 2) higher at the irrigated compared to the

Table 2 Correlation coefficients and p-values from linear regressions between soil moisture and ecosystem $\mathrm{CO}_{2}$ fluxes

\begin{tabular}{llllll}
\hline & \multicolumn{2}{l}{$r^{2}$} & & \multicolumn{2}{l}{$P$-value } \\
\cline { 2 - 3 } & Unirr & Irr & & Unirr & Irr \\
\hline NEE $_{1800}$ & 0.47 & 0.55 & & 0.2 & 0.15 \\
Assimilation & 0.79 & 0.80 & 0.04 & 0.04 \\
$\mathrm{R}_{\text {eco }}$ & 0.89 & 0.87 & 0.02 & 0.02 \\
$\mathrm{R}_{\text {soil }}$ & 0.85 & 0.94 & 0.02 & 0.006 \\
$\mathrm{R}_{\text {canopy }}$ & 0.78 & 0.71 & 0.05 & 0.07 \\
\hline
\end{tabular}

$n=5, \alpha=0.1$, unirr $=$ unirrigated, irr $=$ irrigated unirrigated plots during the growing season $(P$-values from paired $t$-tests: site 1: $P=0.02$, site $2: P=0.007$; Fig. 4). At site 1, where soils were shallow (Table 1), the stimulation of $\mathrm{R}_{\mathrm{eco}}$ by irrigation was due to a stimulation in $\mathrm{R}_{\text {soil }}(P=0.009)$, which was between $4 \%$ and $36 \%$ higher at the irrigated compared to the unirrigated plots during May to September. At site 2, with very deep soils (Table 1 ), differences in $R_{\text {eco }}$ were associated with significant increases in $\mathrm{R}_{\text {canopy }}$ $(P=0.05)$, which were between $26 \%$ and $52 \%$ higher at the irrigated compared to the unirrigated plots (Fig. 4). Irrigation also increased Assimilation by $8-64 \%(P=0.08$; Fig. 4$)$ and $\mathrm{NEE}_{1800}$ by $20-$ $2200 \%$ ( $P=0.08$; Fig. 4). $\mathrm{NEE}_{1800}$ also increased at the wettest site (site 5), which accumulated 1-41\% more net $\mathrm{CO}_{2}\left(\mathrm{NEE}_{1800}\right)$ when watered $(P=0.06$; Fig. 4). In contrast, no irrigation effects on ecosystem $\mathrm{CO}_{2}$ exchanges were detected at the two sites with intermediate soil moisture (sites 3 and 4; Fig. 4).

Assimilation (irr: $P=0.008$, unirr: $P=0.03$ ), $\mathrm{R}_{\text {eco }}$ (irr: $P=0.01$, unirr: $P=0.02$ ), and $\mathrm{R}_{\text {soil }}$ (irr: $P=0.005$, unirr: $P=0.007$ ) significantly differed over the course of the growing season, with highest fluxes at peak biomass (sites 1,2,4: July; sites 3,5: August) and lowest fluxes in May and September. $\mathrm{NEE}_{1800}$ and $\mathrm{R}_{\text {canopy }}$ values trended to be lower in May and September compared to June, July and August; however, no statistical differences were detected (NEE 1800 irr: $P=0.11$, unirr: $P=0.43 ; \mathrm{R}_{\text {canopy }}$ irr: $P=0.28$, unirr: $P=0.15$ ), because of large measurement variations. All the ecosystem $\mathrm{CO}_{2}$ fluxes measured during a specific month of measurement were closely related to shoot biomass $(P<0.05$ for all linear regressions). When examining the effect of irrigation on $\mathrm{CO}_{2}$ fluxes for each month separately, we found no significant difference in any ecosystem $\mathrm{CO}_{2}$ flux variable measured until late in the season: in September, irrigation increased $\mathrm{R}_{\text {eco }}$ by $5-40 \%(P=0.05)$, Assimilation by $13 \%$ and $61 \%(P=0.006), \mathrm{R}_{\text {soil }}$ by $4 \%$ and $36 \%(P=0.07)$, and $\mathrm{NEE}_{1800}$ by $120-2200 \%$ $(P=0.008)$ among sites (Fig. 5). No significant difference was detected between irrigated and unirrigated plots for $\mathrm{R}_{\text {canopy }}$ in September (Fig. 5).

\section{Discussion}

Similar to this study, we previously found (Risch and Frank 2006) a close association between soil moisture 


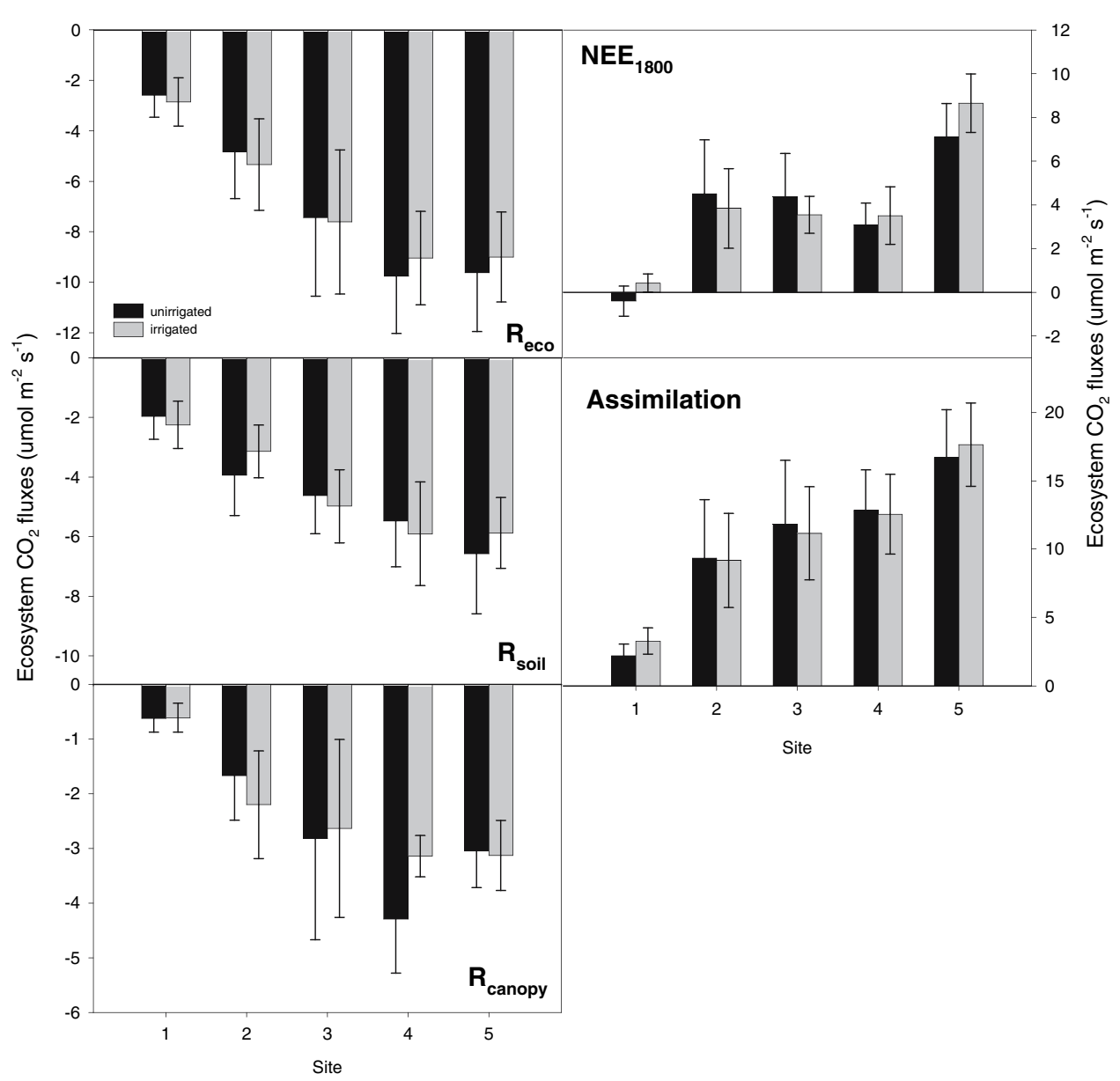

Fig. 3 Average net ecosystem $\mathrm{CO}_{2}$ exchange $\left(\mathrm{NEE}_{1800}\right)$, gross assimilation (Assimilation), and ecosystem $\left(\mathrm{R}_{\mathrm{eco}}\right)$, soil $\left(\mathrm{R}_{\text {soil }}\right)$ and canopy $\left(\mathrm{R}_{\text {canopy }}\right)$ respiration for irrigated and unirrigated plots at each of the five study sites. Negative values are defined as $\mathrm{CO}_{2}$ leaving the ecosystem, while positive values indicate

and $\mathrm{CO}_{2}$ fluxes when measuring ecosystem $\mathrm{CO}_{2}$ exchange in grazed and ungrazed grassland across the landscape in Yellowstone National Park (USA) during the 2004 growing season. Strong correlations between these parameters were also detected in studies conducted in other grassland ecosystems (e.g., Meyers 2001; Flanagan et al. 2002; Xu and Baldocchi 2004; Kato et al. 2004; Flanagan and Johnson 2005; Li et al. 2005). Thus, changes in precipitation regimes, as a result of climate change that alter plant and soil processes (Laurenroth and Sala 1992; Knapp and Smith 2001), may have significant consequences on the amount of $\mathrm{C}$ stored and released from grassland ecosystems. However, given the characteristically large amount of spatial
$\mathrm{CO}_{2}$ taken up by the vegetation. Error bars indicate the standard error calculated from the measurements conducted over the course of the season at each site. Site $1=$ Crystal Bench, Site $2=$ Specimen Ridge, Site $3=$ Canyon, Site $4=$ Mammoth Hot Springs, Site $5=$ Norris

variation in plant and soil properties in grassland habitat, ecosystem responses to changes in precipitation regimes may be heterogeneous. We found that increasing precipitation by $50 \%$ of the monthly 30 year average only had an effect on increasing $\mathrm{CO}_{2}$ respiration $\left(\mathrm{R}_{\mathrm{eco}}, \mathrm{R}_{\text {soil }}, \mathrm{R}_{\text {canopy }}\right)$ at the two driest sites (sites 1 and 2), and net $\mathrm{CO}_{2}$ storage $\left(\mathrm{NEE}_{1800}\right)$ at the driest (site 1) and the wettest site (site 5). The two sites with intermediate soil moisture, 3 and 4 , were unaffected by supplemental water. Thus, $\mathrm{CO}_{2}$ flows were water-limited at sites 1, 2 and 5, and non-limited at sites 3 and 4 during the average moisture conditions of the 2005 growing season.

Potential explanations for the differences in patterns of water-limitation across the Yellowstone landscape 


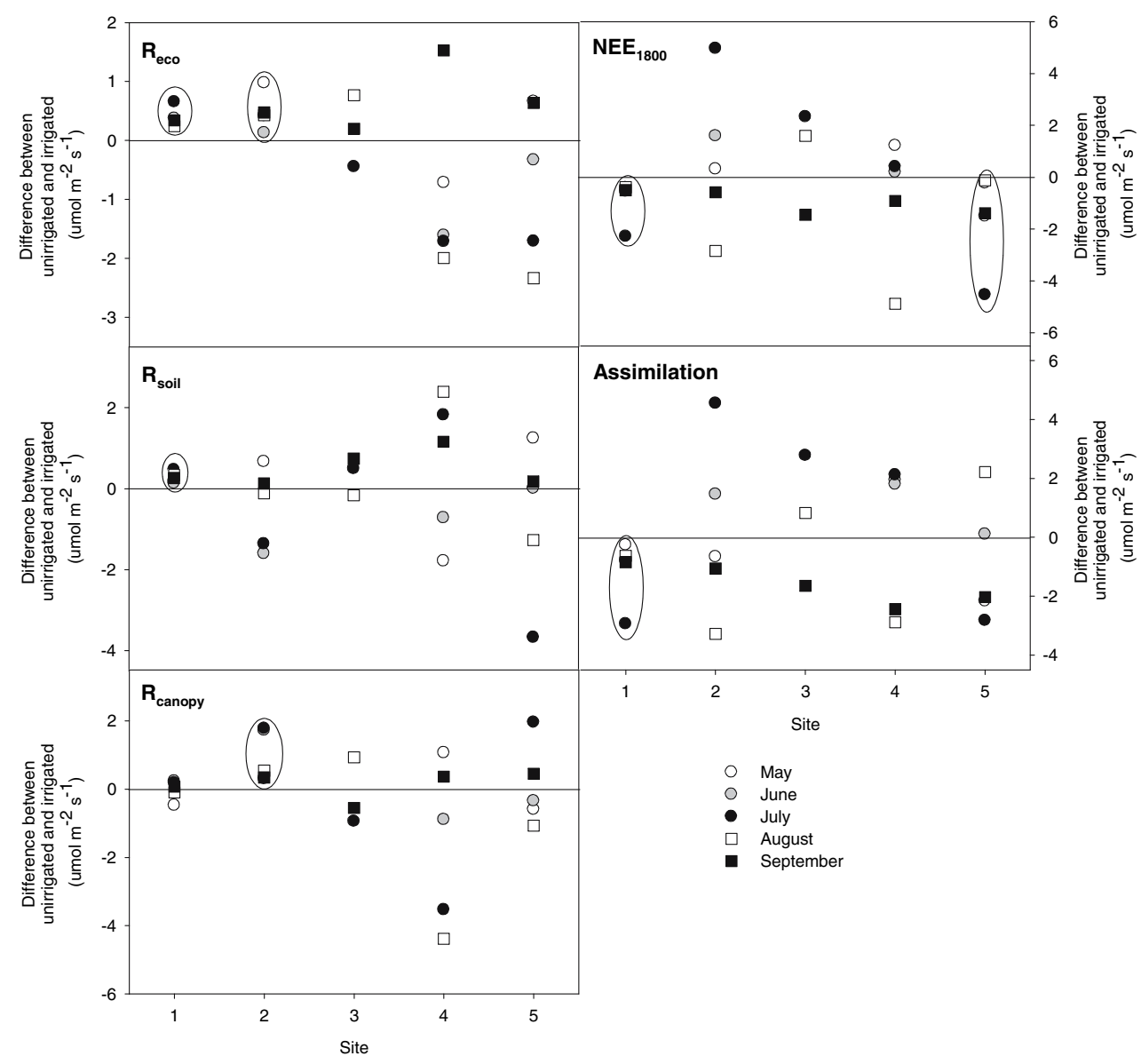

Fig. 4 Differences in net ecosystem $\mathrm{CO}_{2}$ exchange ( $\mathrm{NEE}_{1800}$ ), gross assimilation (Assimilation), and ecosystem $\left(\mathrm{R}_{\mathrm{eco}}\right)$, soil $\left(\mathrm{R}_{\text {soil }}\right)$ and canopy $\left(\mathrm{R}_{\text {canopy }}\right)$ respiration between the irrigated and unirrigated plots at the five study sites. For $R_{\mathrm{eco}}, \mathrm{R}_{\text {soil }}$, and $\mathrm{R}_{\text {canopy, }}$ positive differences indicate that fluxes were higher at the irrigated compared to the unirrigated plots. For $\mathrm{NEE}_{1800}$

could be related to differences in soil (e.g., chemical and physical properties, hydrology) and vegetation (e.g., water use efficiencies, total biomass, vegetation composition, density of plants) properties among the five locations (e.g., Silletti and Knapp 2001; Farmer et al. 2003). Irrigation increased soil moisture the most at sites 1 and 2, which had the sandiest soils among the sites. Sand-rich soils are known to have higher rates of percolation and lower water retention compared to clay rich soils (e.g., English et al. 2005). Consequently, the regular water additions in our study appeared to have especially helped to maintain higher soil moisture levels in grasslands where water from natural rainfall events likely drained quickly through the soil. The reason for finding a positive response of $\mathrm{CO}_{2}$ fluxes to and Assimilation, negative values indicate higher rates at the irrigated plots. Ellipses denote significant treatment effects on ecosystem $\mathrm{CO}_{2}$ fluxes at a specific site based on paired $t$-tests $(\alpha=0.1)$. Site $1=$ Crystal Bench, Site $2=$ Specimen Ridge, Site 3 = Canyon, Site $4=$ Mammoth Hot Springs, Site $5=$ Norris

water additions at the wettest (site 5), but not at the two sites ( 3 and 4 ) located in the middle of our gradient, is less clear. Potential explanations include the composition and structure of the vegetation growing at this site. The plant species growing at site 5 , where the available resources were greatest among the sites, likely were stronger competitors then the dominating plant species found at sites 3 and 4 (Grime 1979). Consequently, these competition-adapted plants may have been more responsive to even small changes in resource availability. Further, the contrasting responses detected between sites 3/4 and site 5 could be related to differences in the number of individual plants growing per $\mathrm{m}^{2}$ grassland (plant density; site 3 : $\sim 1,650$ tillers $\mathrm{m}^{-2}$; site $4: \sim 2,050$ tillers $\mathrm{m}^{-2}$; site 5 : 


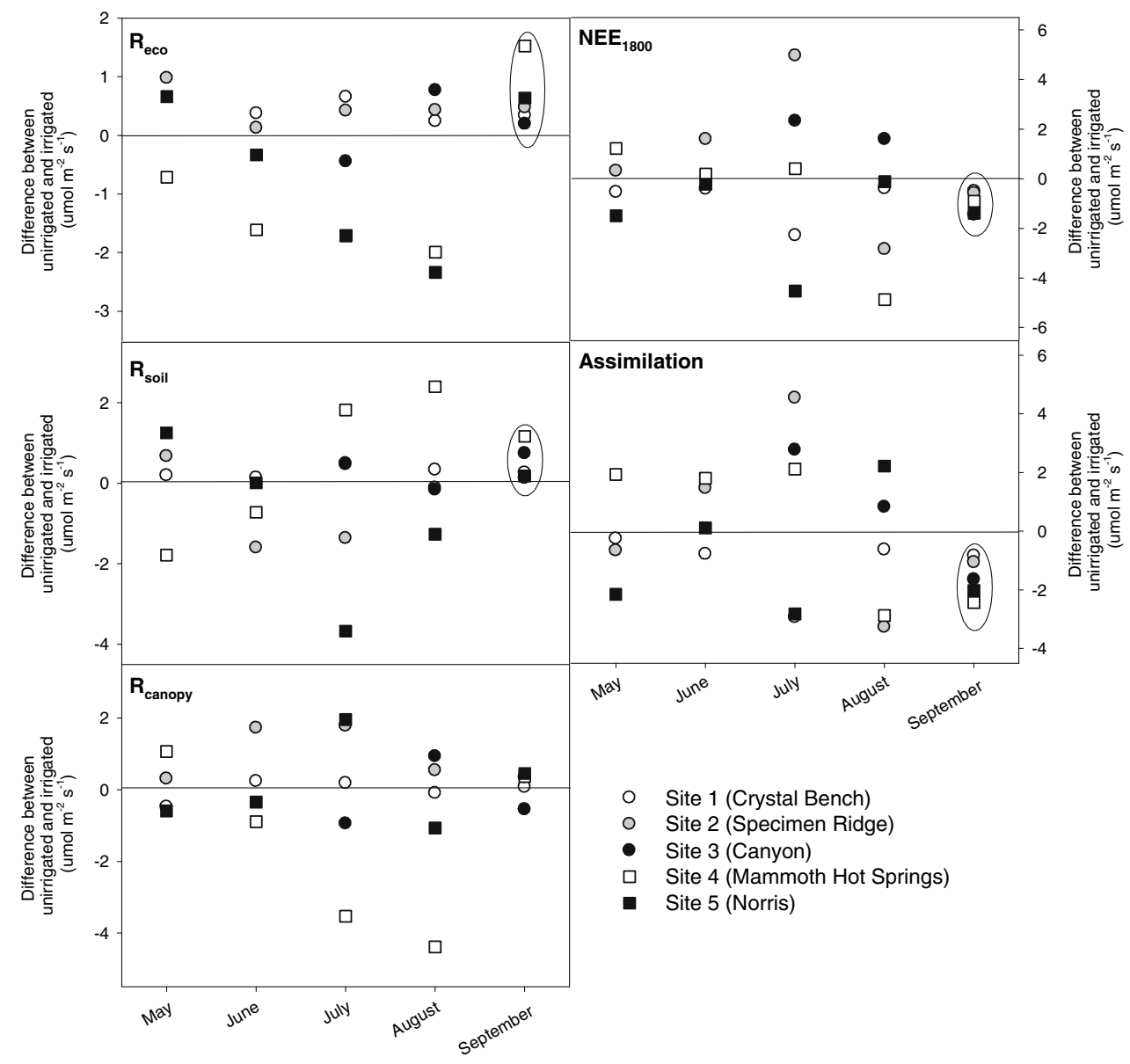

Fig. 5 Differences in net ecosystem $\mathrm{CO}_{2}$ exchange ( $\left.\mathrm{NEE}_{1800}\right)$, gross assimilation (Assimilation), and ecosystem $\left(\mathrm{R}_{\mathrm{eco}}\right)$, soil $\left(\mathrm{R}_{\text {soil }}\right)$ and canopy $\left(\mathrm{R}_{\text {canopy }}\right)$ respiration between the irrigated and unirrigated plots over the course of the growing season. For $\mathrm{R}_{\mathrm{eco}}, \mathrm{R}_{\text {soil }}$, and $\mathrm{R}_{\text {canopy, }}$ positive differences indicate that

$\sim 2,700$ tillers $\mathrm{m}^{-2}$; unpublished data). Knapp and Smith (2001) suggested that vegetation types with low numbers of plants per area would respond less to increases in soil moisture compared to vegetation types with high density of plants (i.e., the meristem limitation hypothesis). Corroborating evidence for Knapp and Smith's (2001) hypothesis comes from Yahdjian and Sala (2006), who reported differences in the response of grassland to irrigation related to plant density when treating grassland with water additions after several years of experimental drought in Patagonia (Argentina). In their study, plant density decreased with increasing drought level, which resulted in a reduced response to subsequent water additions (Yahdjian and Sala 2006). fluxes were higher at the irrigated compared to the unirrigated plots. For $\mathrm{NEE}_{1800}$ and Assimilation, negative values indicate higher values at the irrigated plots. Ellipses denote significant treatment effects on ecosystem $\mathrm{CO}_{2}$ fluxes in a specific month, based on paired $t$-tests $(\alpha=0.1)$

When considering the response in ecosystem $\mathrm{CO}_{2}$ exchanges of all our sites during the growing season, we found no statistically significant difference in fluxes until late in the season. In September all the irrigated plots had significantly higher $\mathrm{NEE}_{1800}$, Assimilation, $\mathrm{R}_{\text {eco }}$ and $\mathrm{R}_{\text {soil }}$ compared to the unirrigated plots. Consequently, in September, water-limitation occurred at all the sites. The higher fluxes at the irrigated plots late in the growing season likely originated from delayed senescence of plants at the irrigated compared to the unirrigated plots. Less dead biomass was observed on the irrigated than on the unirrigated plots (A. Risch, personal observations). Similar to our study, increased soil moisture led to longer plant survival and later peak biomass in pot 
experiments (Mamolos et al. 2001; Yang et al. 2001). Irrigation-delayed senescence also was found in a field experiment with corn in New Zealand (Stone et al. 2001). Higher $\mathbf{R}_{\text {soil }}$ at the irrigated plots in September might have been caused by greater root and soil microbial respiration. For example, Liu and Li (2005) found increased root respiration under well watered compared to water-limited conditions in a greenhouse experiment with wheat. When irrigating the high arctic semi-desert of Greenland, Illeris et al. (2003) found the water addition led to higher soil microbial activity. A similar late-season increase in $\mathrm{R}_{\text {eco }}$ by irrigation, along with an absence of an early-season response, as in our study, was reported by Chimner and Welker (2005) in a mixed grass prairie in Wyoming, USA.

Our results showed a strong heterogenous response of grassland to water additions during a growing season of approximately average precipitation: the sites at the driest and wettest ends of the topo-edaphic gradient responded positively to irrigation, but no irrigation effect was detected at sites located in the middle of the gradient. At the dry end, the positive responses likely were associated with soil properties, while plant attributes may have caused the increases in ecosystem $\mathrm{CO}_{2}$ fluxes at the wettest end of the gradient. The regular water additions also had an effect on ecosystem $\mathrm{CO}_{2}$ fluxes at all sites in September, by delaying plant senescence and potentially increasing soil microbial activity. Thus, it is likely that years of above-average amounts of precipitation would lead to increases in net $\mathrm{C}$ gains late in the season, which in turn could have a positive effect on ecosystem $\mathrm{C}$ cycling in the following year. Further, if long-term trends in precipitation change, as predicted for many regions of North America (e.g., Cubasch et al. 2001), soil moisture gradients and the distribution of plant species will likely shift arcoss the landscape. Such changes, in turn, could affect how this heterogeneous landcape responds to variable climate.

Acknowledgements We thank Brian Wilsey, Chris Kolodziejczyk and the Syracuse University Physics shop for their help with developing the chamber system. We thank Vincent Green, Monika Wysser, Anna Stewart, and Timothy DePriest for their assistance in the field, Eric Hellquist for assistance with plant identification, and Martin Schütz for helpful comments on the manuscript. We are grateful for the support by the Yellowstone National Park Service administration. This project was funded by US-NSF grant DEB-0318716 and Swiss-NSF fellowships PBEZ-104320 and PBEZA-104320.

\section{References}

Abrams MD, Knapp AK, Hulbert LC (1986) A 10-year record of aboveground biomass in a Kansas tallgrass prairie: effects of fire and topographic position. Am J Bot 73:1509-1515

Anderson JM (1991) The effects of climate change on decomposition processes in grassland and coniferous forests. Ecol Appl 1:326-347

Bouma TJ, Bryla DR (2000) On the assessment of root and soil respiration for soils of different textures: interactions with soil moisture contents and soil $\mathrm{CO}_{2}$ concentrations. Plant Soil 227:215-221

Briggs JM, Knapp AK (1995) Interannual variability in primary production in tallgrass prairie: climate, soil moisture, topographic position, and fire as determinants of aboveground biomass. Am J Bot 82:1024-1030

Brown JH, Valone TJ, Curtin CG (1997) REorganiation of an arid ecosystem in response to recent climate change. PNAS 94:9729-9733

Chimner RA, Welker JM (2005) Ecosystem respiration responses to experimental manipulations of winter and summer precipitation in a Mixedgrass Prairie, WY, USA. Biogeochemistry 73:257-270

Cubasch C, Meehl GA, Boer GJ, Stouffer M, Dix A, Senior CA, Raper S, Yap KS (2001) Projections of future climate change. In: Houghton JT, Ding Y, Griggs DJ, Noguer M, van der Linden PJ, Dai X, Maskell K, Johnson CA (eds) Climate change 2001: the scientific basis. Contribution of Working Group 1 to the third assessement report of the Intergovernmental Panel on Climate Change. Cambridge University Press, Cambridge UK, and New York NY, USA, $881 \mathrm{pp}$

Davidson EA, Savage K, Verchot LV, Navarro R (2002) Minimizing artifacts and biases in chamber-based measurements of soil respiration. Agr Forest Meteorol 113:21-37

English NB, Weltzin JF, Fravolini A, Thomas L. Williams DG (2005) The influence of soil texture and vegetation on soil moisture under rainout shelters in a semi-desert grassland. J Arid Environ 63:324-343

Epstein HE, Burke IC, Lauenroth WK (2002) Regional patterns of decomposition and primary production rates in the U.S. great plains. Ecology 83:320-327

Eswaran H, van den Berg E, Reich P (1993) Organic carbon in soils of the world. Soil Sci Soc Am J 57:192-194

Farmer D, Sivapalan M, Jothityangkoon C (2003) Climate, soil, and vegetation controls upon the variability of water balance in temperate and semiarid landscapes: Downward approach to water balance analysis. Water Resour Res 39:1035 SWC1-21

Fay PA, Carlisle JD, Knapp AK, Blair JM, Collins SL (2000) Altering rainfall timing and quantity in a mesic grassland ecosystem: design and performance of rainfall manipulation shelters. Ecosystems 3:308-319

Fay PA, Knapp AK, Blair JM, Carlisle JD, Danner BT, McCarron JK (2003) Rainfall timing, soil moisture dynamics, and plant response in a mesic tallgrass prairie ecosystem. In: Weltzin JF, McPherson GR (eds) Precipitation regimes and terrestrial ecosystems. A North 
American Perspective, University of Arizona Press, pp 147-163

Flanagan LB, Wever LA, Carlson PJ (2002) Seasonal and interannual variation in carbon dioxide exchange and carbon balance in a northern temperate grassland. Global Change Biol 8:599-615

Flanagan LB, Johnson BG (2005) Interacting effects of temperature, soil moisture and plant biomass production on ecosystem respiration in a northern temperate grassland. Agr Forest Meteorol 130:237-253

Frank DA, McNaughton SJ (1990) Aboveground biomass estimation with the canopy intercept method: a plant growth form caveat. Oikos 57:57-60

Frank DA, McNaughton SJ (1992) The ecology of plants, large mammalian herbivores and drought in Yellowstone National Park. Ecology 73:2043-2058

Frank DA, Inouye RS., Huntly N, Minshall GW, Anderson JE (1994) The biogeochemistry of a north-temperate grassland with native ungulates: nitrogen dynamics in Yellowstone National Park. Biogeochemistry 26:163-188

Grime JP (1979) Plant strategies and vegetation processes. Wiley, Chichester

Harper CW, Blair JM, Fay PH, Knapp AK, Carlisle JD (2005) Increased rainfall variability and reduced rainfall amount decreases soil $\mathrm{CO}_{2}$ flux in a grassland ecosystem. Global Change Biol 11:322-334

Healy RW, Striegel RG, Russell TF, Hutchinson GL, Livingston GP (1996) Numerical evaluation of astatic-chamber measurements of soil-atmosphere gas exchange: identification of physical processes. Soil Sci Soc Am J 60:740-747

Hooper DU, Cardon ZG, Chapin III FS, Durant M (2002) Corrected calculations for soil and ecosystem measurements of $\mathrm{CO}_{2}$ flux using the LICOR 6200 portable photosynthesis system. Oecologia 132:1-11

Hunt JE, Kelliher FM, McSeveny TM, Byers JN (2002) Evaporatoin and carbon dioxide exchange between the atmosphere and a tussock grassland during a summer drought. Agr Forest Meteorol 111:65-82

Hunt JE, Kelliher FM, T.M. McSeveny TM, Ross DJ, Whitehead D (2004) Long-term carbon exchange in a sparse, seasonally dry tussock grassland. Global Change Biol 10:1785-1800

Huxman TE, Cable JM, Ignace DD, Eilts JA, English NB, Weltzin J, Wiliams DG (2004a) Response of net ecosystem gas exchange to a simulated precipitation pulse in a semi-arid grassland: the role of native versus non-native grasses and soil texture. Oecologia 141:295-305

Huxman TE, Snyder KA, Tissue D, Leffler AJ, Ogle K, Pockman WT, Sandquist DR, Potts DL, Schwinning S (2004b) Precipitation pulses and carbon fluxes in semiarid and arid ecosystems. Oecologia 141:254-268

Illeris L, Michelsen A, Jonasson S (2003) Soil plus root respiration and microbial biomass following water, nitrogen, and phosphorus application at a high arctic semi desert. Biogeochemistry 65:15-29

Jaksic V, Kiely G, Albertson J, Oren R, Katul G, Leahy P, Byrne KA (2006) Net ecosystem exchange of grassland in contrasting wet and dry years. Agr Forest Meteorol 139:323-334

Kato T, Tang Y, Gu S, Cui X, Hirota M, Du M, Li Y, Zhao X, Oikawa T (2004) Carbon dioxide exchange between the atmosphere and an alpine meadow ecosystem on the Qinghai-Tibetan Plateau, China. Agr Forest Meteorol 124:121-134

Knapp AK, Fahnestock JT, Hamburg SJ, Statland LB, Seastedt TR, Schimel DS (1993) Landscape patterns in soil-plant water relations and primary production in tallgrass prairie. Ecology 74:549-560

Knapp AK, Smith MD (2001) Variation among biomass and temporal dynamics of aboveground primary production. Science 291:481-484

Knapp AK, Fay PA, Blair JM, Collins SL, Smith MD, Carlisle JD, Harper CW, Danner BT, Lett MS, McCarron JK (2002) Rainfall variability, carbon cycling and plant species diversity in a mesic grassland. Science 298:22022205

Kozlowski TT (1984) Plant responses to flooding of soil. BioScience 34:162-167

Lauenroth WK, Sala OE (1992) Long-term forage production of North American shortgrass steppe. Ecol Appl 2:397-403

Li SG, Asanuma J, Eugster W, Kotani A, Liu JJ, Urano T, Oikawa T, Davaa G, Oyunbaatar D, Sugita M (2005) Net ecosystem carbon dioxide exchange over grazed steppe in central Mongolia. Global Change Biol 11:1-15

Lieth H (1978) Pattern of primary productivity in the biosphere. Hutchinson \& Ross, Stroudsberg, PA

Liu HS, Li FM (2005) Root respiration, photosynthesis and grain yield of two spring wheat in response to soil drying. Plant Growth Regul 46:233-240

Liu X, Wan S, Su B, Hui D, Luo Y (2002) Response of soil $\mathrm{CO}_{2}$ efflux to water manipulations in a tallgrass prairie ecosystem. Plant Soil 240:213-223

Mamolos AP, Veresoglou DS, Noitsakis V, Gerakis A (2001) Differential drought tolerance of five plant species in Mediterranean lowland grasslands. J Arid Environ 49:329-341

Meyers TP (2001) A comparison of summertime water and $\mathrm{CO}_{2}$ fluxes over rangeland for well watered and drought conditions. Agr Forest Meteorol 106:205-214

Oreskes N (2004) The scientific consensus on climate change. Science 306:1686

Risch AC, Frank DA (2006) Carbon dioxide fluxes in a spatially and temporally heterogeneous temperate grassland. Oecologia 147:291-302

Ruimy A, Jarvis PG, Baldochhi DD, Saugier B (1995) $\mathrm{CO}_{2}$ fluxes over plant canopies and sloar radiation: a review. Adv Ecol Res 26:259-274

Sala OE, Laurenroth WK (1982) Small rainfall events: an ecological role in semiarid regions. Oecologia 53:301-304

Schimel D, Stillwell MA, Woodmansee RG (1985) Biolgeochemistry of $\mathrm{C}, \mathrm{N}$, and $\mathrm{P}$ in a soil cantena of the shortgrass steppe. Ecology 66:276-283

Silletti AM, Knapp AK (2001) Responses of the codominant grassland specis Andropogon gerardii and Sorghastrum nutans to long-term manipulations of nitrogen and water. Am Mid Nat 145:159-167

Soussana JF, Fuhrer J, Jones M, Van Amstel A (2007) The greenhouse gas balance of grasslands in Europe. Special issue, Agr Ecosyst Environ 121:1-192

Stone PJ, Wilson DR, Jamison PD, Gillespie RN (2001) Water deficit effects on sweet corn. II. Canopy development. Austr J Agric Res 52:115-126 
Suyker AE, Verma SB, Burba GG (2003) Interannual variability in net $\mathrm{CO}_{2}$ exchange of a native tallgrass prairie. Global Change Biol 9:1-11

Turner CL, Blair JM, Schartz RJ, Neel JC (1997) Soil N and plant responses to fire, topography, and supplemental $\mathrm{N}$ in tallgrass prarie. Ecology 78:1832-1843

Tylor AR, Schrote D, Pflug A, Wolters V (2004) Responses of different decomposer communities to the manipulatin of moisture availability: potential effects of changing precipitation patterns. Global Change Biol 10:1313-1324

Wilsey BJ, Parent G, Roulet NT, Moore TR, Potvin C (2002) Tropical pasture carbon cycling: relationships between $\mathrm{C}$ source/sink, above-ground biomass and grazing. Ecol Lett 5:367-376

$\mathrm{Xu} \mathrm{L}$, Baldocchi DD (2004) Seasonal variation in carbon dioxide exchange over a Mediterranean annual grassland in California. Agr Forest Meteorol 1 123:79-96

Yahdjian L, Sala OE (2006) Vegetation structure constrains primary production responses to water availability in the Patagonian steppe. Ecology 87:952-962

Yang J, Zhang J, Wang Z, Zhu Q, Liu L (2001) Water deficit-induced senescence and its relationship to the remobilization of pre-stored carbon in wheat during grain filling. Agr J 93:196-206 